\title{
New tools for preimplantation genetic diagnosis of Huntington's disease and their clinical applications
}

\author{
Céline Moutou ${ }^{1}$, Nathalie Gardes ${ }^{1}$ and Stéphane Viville ${ }^{*, 1,2}$
}

\author{
${ }^{1}$ Service de Biologie de la Reproduction - SIHCUS-CMCO, CHU de Strasbourg, 19, rue Louis Pasteur, BP120, 67303 \\ Schiltigheim Cedex, France; ${ }^{2}$ Institut de Génétique et de Biologie Moléculaire et Cellulaire, CNRS/INSERM/ULP, \\ BP163 1, rue Laurent Fries, F-67400 Illkirch Cedex, CU de Strasbourg, France
}

Huntington's disease (HD) is a late-onset neurodegenerative disorder transmitted as an autosomal dominant trait. The causative mutation was characterised in 1993. For HD carriers willing to create a family, prenatal diagnosis (PND) or preimplantation genetic diagnosis (PGD) based on the mutation identification can be offered. For at-risk persons who do not want to undergo presymptomatic testing (PT), an exclusion test can be proposed. With such a test, only fœtuses or embryos that inherit an allele from the unaffected grandparent are considered as unaffected. In cases of PND, if the fœtus has one allele of the affected grandparent, termination of pregnancy is proposed. In cases of PGD, only not at-risk embryos are transferred. Since the beginning of our PGD activity, we have had 43 PGD referrals for HD, of which 24 were from patients who know their genetic status and 19 from patients who do not wish to perform PT. We have developed 12 multiplex fluorescent PCR protocols applied at the single-cell level for PGD, some of which target the CAG repeat while others use two different polymorphic microsatellites. We present here these different protocols and their clinical applications, as well as the characterisation and use of a new highly polymorphic intragenic marker. Between May 2001 and December 2003, 39 PGD cycles have been performed for 17 couples, 11 of whom had a known genetic status and six who did not wish to perform PT, resulting in four pregnancies.

European Journal of Human Genetics (2004) 12, 1007-1014. doi:10.1038/sj.ejhg.5201291

Published online 6 October 2004

Keywords: multiplex fluorescent PCR; preimplantation genetic diagnosis; PGD; Huntington's disease; exclusion test

\section{Introduction}

Huntington's disease (HD) is a progressive neurodegenerative disorder characterised by a selective neural cell death at the level of the basal ganglia and cerebral cortex, resulting in choreic movements, dementia, personality changes and psychiatric disease. The mean age of onset is 40 years. The disease is incurable with death occurring on average 16 years after onset. HD is transmitted as an

*Correspondence: $\operatorname{Dr} S$ Viville, Institut de Génétique et de Biologie Moléculaire et Cellulaire, CNRS/INSERM/ULP, BP163 1, rue Laurent Fries, F-67400 Illkirch Cedex, CU de Strasbourg, France; Tel: + 333886533 22; Fax: + 333886532 01; E-mail: viville@igbmc.u-strasbg.fr

Received 23 March 2004; revised 18 June 2004; accepted 25 June 2004 autosomal dominant trait and occurs in fewer than 1 in 5000 people (OMIM: 143100). The causative mutation is an expansion of an unstable CAG triplet repeats in the first exon of the IT15 gene on chromosome 4 (4p16). ${ }^{1}$

The late onset of HD raises the difficult question of presymptomatic testing (PT). Indeed, relatives of an HD patient may or may not wish to know their own genetic status before the manifestation of clinical signs. In the absence of treatment, only a low percentage of at-risk relatives wish to be tested. ${ }^{2-4}$ For at-risk persons who know or do not know their genetic status and wish to create a family, this question becomes even more stringent and different options are now available. Indeed, besides adoption or gamete donation, they can opt for prenatal 
diagnosis (PND) with possible termination of pregnancy (TOP) or preimplantation genetic diagnosis (PGD) ${ }^{5}$ with selective uterine transfer of unaffected embryos.

For at-risk persons not wishing to perform PT, an exclusion test can be proposed. Such a test is based on identifying the origin of the two 4p16 alleles. Fœtuses or embryos that inherit alleles from unaffected grandparents are considered as unaffected. In the cases of PND, if the fœtus has one allele of the affected grandparent, a TOP is proposed even if this fœetus is only at $50 \%$ risk. This represents the major drawback of this method. In the case of PGD, only embryos for which the risk has been excluded are transferred. Therefore, the major difference between the methods resides in the avoidance of TOP of a possibly unaffected foetus with PGD. Concerning PGD, an alternative method, termed nondisclosure, has been proposed. ${ }^{6,7}$ In this method, embryos are analysed for the CAG repeat without revealing to the patients any detail of the course of the PGD procedure. Only embryos without a CAG expansion are transferred. ${ }^{8}$ This implies that the atrisk member of the couple has to face a new situation. Indeed, he/she goes from a situation where he/she does not know, but knows that no one knows to a situation where he/she does not know, but knows that someone knows.

PGD for HD (HD-PGD) represents the first request at our PGD centre. Indeed, since the beginning of our activity in late 1999, we have had 43 referrals: 24 from patients knowing their genetic status (group I) and 19 from people who do not wish PT (group II). We have developed 12 multiplex fluorescent PCR tests, some of which target the CAG repeat and others of which use two different polymorphic microsatellites. This project obtained the approval of the local pluri-disciplinary PND centre as requested by French law $^{9}$ and favourable advice from the National Ethical Committee (advice no. 72, July 2002, http://www.ccne-ethique.fr/). We present these different protocols, and their clinical application as well as the characterisation and use of a new highly polymorphic intragenic marker. Between May 2001 and December 2003, 39 cycles have been performed for 17 couples, 11 with a known genetic status and six without previous PT, resulting in four pregnancies.

\section{Materials and methods}

\section{Single lymphoblast testing and embryo biopsy}

Six Epstein-Barr transformed lymphoblast cell lines were used to perform single-cell analysis. The choice of the cell line used for each test was based on their genotype at the amplified loci. Heterozygous cells were chosen to determine overall allele dropout (ADO) rates. Tubing and embryo biopsy procedures were performed as previously described. ${ }^{10,11}$

\section{PCR reactions}

Cell treatments were as described previously. ${ }^{10}$ PCR primer sequences are given in Table 1 . One primer of each pair was fluorescently labelled with the 6-fam, ned or hex fluorochrome (Applied Biosystems, Warrington, UK). Localisation and heterozygosity rates of the different markers used are given in Figure 1. PCR conditions are given in Table 2. PCR products were analysed on an ABI3100 automated sequencer (Applied Biosystems, Warrington, UK). PCR efficiency was calculated from samples for which a PCR signal was obtained for at least one tested locus.

Table 1 Primer sequences

\begin{tabular}{|c|c|c|c|c|}
\hline Locus-primer set & Primer sequence & Labelling & Fragment size range (bp) & Max het (\%) \\
\hline \multirow[t]{2}{*}{ CAG } & f-ATGGCGACCCTGGAAAAGCTGATGA & ned & & \\
\hline & r-GGCGGCTGAGGAAGCTGAGGA & & 154 for 16 CAG & - \\
\hline \multirow[t]{2}{*}{ D4S3038 } & f-GAAGACCAGCATTCGG & hex & & \\
\hline & r-GGTTTAATACACAGTAATTGTTCA & & $200-220$ & 78 \\
\hline D4S1614 & $\begin{array}{l}\text { f-CATCTAGGAGAATCAGTACTTGG } \\
\text { r-TTACСATGAGCATATICCA }\end{array}$ & hex & $140-150$ & 64 \\
\hline \multirow[t]{2}{*}{ D4S127 } & f-CCTCTGTTTGCAATCCATTT & fam & ט & \\
\hline & r-GTCCCTTGCATGCCCTGGCT & & $150-160$ & 71 \\
\hline $\mathrm{D} 4 \mathrm{~S} 127.2^{\mathrm{a}}$ & $\begin{array}{l}\text { f-CCATTTTGCACTACGGAAAGGAGAAG } \\
\text { r-GTCCСTTGCATGCCCTGGCT }\end{array}$ & fam & $230-240$ & 71 \\
\hline I1CAHD & f-TATGCCACTACACTACAACCTG & ned & & \\
\hline \multirow[t]{2}{*}{ I1CAHD. $2^{\mathrm{a}}$} & $\begin{array}{l}\text { r-AGCATGTGGTATTGTCAAAGTG } \\
\text { f-TATGCCACTACACTACAACCTGGGC }\end{array}$ & fam & $135-175$ & 90 \\
\hline & $\begin{array}{l}\text { r-ACCAGCATGTGGTATTGTCAAAGTG } \\
\text { f-CTGCCAATAAACTGGGT }\end{array}$ & ned & $140-180$ & 90 \\
\hline D4S3034 & r-TTGCTCACCAAAGAGGTT & neu & $175-185$ & 62 \\
\hline \multirow[t]{2}{*}{ D4S412 } & f-ACTACCGCCAGGCACT & fam & & \\
\hline & r-CTAAGATATGAAAACCTAAGGGA & & $230-250$ & 77 \\
\hline D4S412.2 $2^{\mathrm{a}}$ & r-TAAGATATGAAAACCTAAGGGATAAAGG & nex & $230-240$ & 77 \\
\hline
\end{tabular}

${ }^{a}$ Second set of primers designed to improve efficiency of certain duplex PCR. 


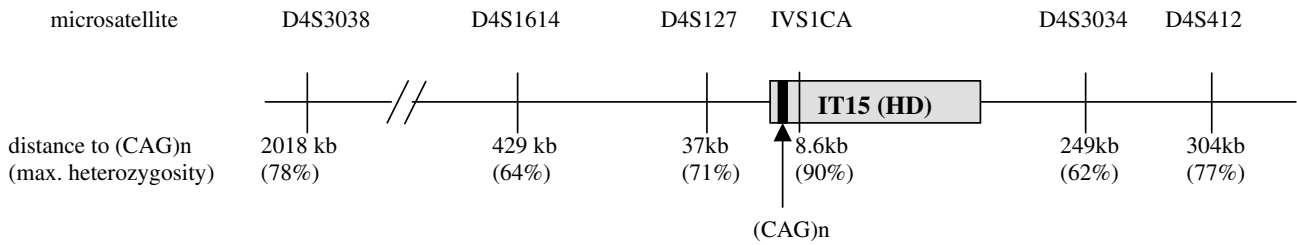

Figure $1 \mathrm{HD}$ locus and the distribution of the different markers used in this study. The distances are expressed in kilobases according to the IT15 gene. The percentage indicates the maximal heterozygosity.

Table 2 PCR conditions for duplex PCRs

\begin{tabular}{|c|c|c|c|c|c|c|}
\hline Primer sets (pmol/reaction) & $\begin{array}{c}\mathrm{MgCl}_{2} \\
(\mathrm{mM})\end{array}$ & $\begin{array}{c}\mathrm{MgSO}_{4} \\
(\mathrm{mM})\end{array}$ & Taq & $\begin{array}{l}\text { Tricine } \\
(20 \mathrm{~mm})\end{array}$ & $\begin{array}{l}\text { Glycerol } \\
(10 \%)\end{array}$ & PCR conditions \\
\hline D4S3038 (10) D4S127 (5) & 1.5 & - & HIFI (Roche) & + & + & $\begin{array}{l}45\left(10^{\prime \prime} \text { at } 94 \text { or } 96^{\circ} \mathrm{C}, 30^{\prime \prime}\right. \\
\left.\text { at } 53^{\circ} \mathrm{C}, 30^{\prime \prime}+2^{\prime \prime} \text { per cycle at } 72^{\circ} \mathrm{C}\right)\end{array}$ \\
\hline $\begin{array}{l}\text { D4S3038 (10) } \\
\text { D4S1614 (10) }\end{array}$ & 2 & - & HIFI (Roche) & + & - & $\begin{array}{l}45\left(10^{\prime \prime} \text { at } 94 \text { or } 96^{\circ} \mathrm{C}, 30^{\prime \prime}\right. \\
\left.\text { at } 54^{\circ} \mathrm{C}, 1^{\prime} \text { at } 72^{\circ} \mathrm{C}\right)\end{array}$ \\
\hline $\begin{array}{l}\text { D4S127 (5) } \\
\text { D4S412(10) }\end{array}$ & 2 & - & HIFI (Roche) & + & - & $\begin{array}{l}45\left(10^{\prime \prime} \text { at } 94 \text { or } 96^{\circ} \mathrm{C}, 30^{\prime \prime}\right. \\
\left.\text { at } 56^{\circ} \mathrm{C}, 30^{\prime \prime} \text { at } 72^{\circ} \mathrm{C}\right)\end{array}$ \\
\hline $\begin{array}{l}\text { D4S127 (5) } \\
\text { D4S3034 (10) }\end{array}$ & 2 & - & HIFI (Roche) & + & - & $\begin{array}{l}45\left(10^{\prime \prime} \text { at } 94 \text { or } 96^{\circ} \mathrm{C}, 30^{\prime \prime}\right. \\
\left.\text { at } 53^{\circ} \mathrm{C}, 30^{\prime \prime} \text { at } 72^{\circ} \mathrm{C}\right)\end{array}$ \\
\hline $\begin{array}{l}\text { D4S1614 (15) } \\
\text { D4S3034 (10) }\end{array}$ & 2 & - & HIFI (Roche) & + & + & $\begin{array}{l}45\left(10^{\prime \prime} \text { at } 94 \text { or } 96^{\circ} \mathrm{C}, 30^{\prime \prime}\right. \\
\left.\text { at } 53^{\circ} \mathrm{C}, 1^{\prime} \text { at } 72^{\circ} \mathrm{C}\right)\end{array}$ \\
\hline $\begin{array}{l}\text { D4S1614 (10) } \\
\text { D4S412 (10) }\end{array}$ & - & 2 & $\begin{array}{l}\text { Platinum HIFI } \\
\text { (Invitrogen) }\end{array}$ & - & - & $\begin{array}{l}45\left(10^{\prime \prime} \text { at } 94 \text { or } 96^{\circ} \mathrm{C}, 30^{\prime \prime}\right. \\
\left.\text { at } 55^{\circ} \mathrm{C}, 1^{\prime} \text { at } 68^{\circ} \mathrm{C}\right)\end{array}$ \\
\hline $\begin{array}{l}\text { D4S3034 (10) } \\
\text { D4S412(10) }\end{array}$ & 2 & - & HIFI (Roche) & + & - & $\begin{array}{l}45\left(10^{\prime \prime} \text { at } 94 \text { or } 96^{\circ} \mathrm{C}, 30^{\prime \prime}\right. \\
\left.\text { at } 54^{\circ} \mathrm{C}, 30^{\prime \prime} \text { at } 72^{\circ} \mathrm{C}\right)\end{array}$ \\
\hline $\begin{array}{l}\text { CAG (10) } \\
\text { D4S127.2 (5) }\end{array}$ & 2 & - & ELT (Roche) & + & - & $\begin{array}{l}45\left(10^{\prime \prime} \text { at } 94 \text { or } 96^{\circ} \mathrm{C}, 30^{\prime \prime}\right. \\
\left.\text { at } 65^{\circ} \mathrm{C}, 1^{\prime} \text { at } 68^{\circ} \mathrm{C}\right)\end{array}$ \\
\hline $\begin{array}{l}\text { CAG (10) } \\
\text { D4S412.2(15) }\end{array}$ & 2 & - & ELT (Roche) & + & - & $\begin{array}{l}45\left(10^{\prime \prime} \text { at } 94 \text { or } 96^{\circ} \mathrm{C}, 30^{\prime \prime}\right. \\
\left.\text { at } 65^{\circ} \mathrm{C}, 1^{\prime} \text { at } 68^{\circ} \mathrm{C}\right)\end{array}$ \\
\hline $\begin{array}{l}\text { I1CAHD (5) } \\
\text { D4S127.2 (3) }\end{array}$ & - & 2 & $\begin{array}{l}\text { Platinum HIFI } \\
\text { (Invitrogen) }\end{array}$ & - & + & $\begin{array}{l}45\left(10^{\prime \prime} \text { at } 94 \text { or } 96^{\circ} \mathrm{C}, 30^{\prime \prime}\right. \\
\left.\text { at } 54^{\circ} \mathrm{C}, 1^{\prime} \text { at } 68^{\circ} \mathrm{C}\right)\end{array}$ \\
\hline $\begin{array}{l}\text { I1CAHD (10) } \\
\text { D4S412.2 (10) }\end{array}$ & 一 & 2 & $\begin{array}{l}\text { Platinum HIFI } \\
\text { (Invitrogen) }\end{array}$ & - & + & $\begin{array}{l}45\left(10^{\prime \prime} \text { at } 94 \text { or } 96^{\circ} \mathrm{C}, 10^{\prime \prime}\right. \\
\left.\text { at } 50^{\circ} \mathrm{C}, 1^{\prime} \text { at } 68^{\circ} \mathrm{C}\right)\end{array}$ \\
\hline $\begin{array}{l}\text { I1CAHD.2 (10) } \\
\text { CAG (10) }\end{array}$ & 2 & - & ELT (Roche) & + & - & $\begin{array}{l}42\left(10^{\prime \prime} \text { at } 94 \text { or } 96^{\circ} \mathrm{C}, 30^{\prime \prime}\right. \\
\left.\text { at } 65^{\circ} \mathrm{C}, 1^{\prime} \text { at } 68^{\circ} \mathrm{C}\right)\end{array}$ \\
\hline
\end{tabular}

\section{Informativity testing for couples requesting PGD}

Genomic DNA from each couple requesting PGD and from their parents was extracted from whole-blood samples using the standard saline protocol. ${ }^{12}$ CAG repeats for couples with known genetic status and haplotype analysis for the different microsatellites were performed using procedures previously described. ${ }^{10}$

For group I patients, we used a simplex PCR amplifying the CAG repeats. ${ }^{5}$ The drawback of this test comes from the difficulty of amplifying the long repeats, meaning that the couple has to carry nonpathological CAG repeats of different sizes. Therefore, in a first instance, we determine the haplotype of the CAG repeat of both members of the couple and, if they are fully informative, we use this test. If the couple is semi-informative or noninformative, we test the parents of the carrier person in order to determine the segregation phase of the mutation. The most informative test is then used. 
For group II patients, in order to avoid the risk of performing fortuitously a PT and to reduce the stressfulness of the procedure, a specific protocol was elaborated. After the first visit to our centre, each couple is sent back to their geneticist. During every consultation, we insist that CAG repeats will not be tested in any case. We take special care to minimise the risk of pointing out a false paternity, especially when the father of the at-risk person is affected. Indeed, a false paternity will result in a presymptomatic diagnosis excluding the risk.

Therefore, we ask for DNA samples from the couple and both parents of the at-risk person. In the first instance, we confirm the diagnosis of the parent diagnosed as HD. Thereafter, we study the informativity of the different markers within the couple. All the informative markers are then tested on the mother's DNA of the at-risk person asking for PGD. If some of them are informative, we do not analyse the father and use the best combination. If the markers are not informative but do present some level of heterozygosity, we test these markers on the father's DNA. If they are shown to be informative, we choose the best duplex PCR for PGD. If they are not informative at all, the procedure is stopped.

\section{Clinical PGDs}

Considering the small number of patients and the urgent need to preserve their privacy, we deliberately present couple and cycle information on an aggregate rather than individual basis. A total of 43 couples requested for HDPGD. Patient ovarian stimulation, oocyte recovery, ICSI and biopsy procedures were carried out as previously described. ${ }^{13,14}$

\section{Results \\ A new highly polymorphic microsatellite in the first intron of the IT15 gene}

Two sequences, 9(CA) or 9(TA) repeats, were used to screen the HD locus. We found one large unpublished CA repeat in the first intron of the IT15 gene. The degree of polymorphism of this new marker (referred as I1CAHD) was established by analysing 74 unrelated individuals from our referrals. The size range of amplicon, and the distribution and frequency of the different alleles are shown in Table 3. This CA repeat showed a heterozygosity of $85 \%$ and a calculated maximal heterozygosity of $90 \%$. Meiotic stability was tested via inheritance analysis in 16 pedigrees: both parents and one of their children were tested for 13 nuclear families, and the mother and one child were available in 10 nuclear families. In total, 36 alleles were tested after transmission through one generation and no instability was observed. Finally, we did not observe any linkage disequilibrium between this marker and the causative HD mutation. Therefore, this marker represents
Table 3 Allele distribution for I1CAHD microsatellite

\begin{tabular}{lcc}
\hline Allele size & No. of chromosomes & Allele frequency (\%) \\
\hline 135 & 1 & 1 \\
145 & 5 & 3 \\
147 & 1 & 1 \\
151 & 6 & 4 \\
153 & 16 & 11 \\
155 & 18 & 12 \\
157 & 21 & 14 \\
159 & 14 & 9 \\
161 & 21 & 14 \\
163 & 8 & 5 \\
165 & 15 & 10 \\
167 & 15 & 10 \\
169 & 4 & 3 \\
171 & 2 & 1 \\
173 & 1 & 1 \\
Total & 148 & - \\
\hline
\end{tabular}

the closest and the most informative marker of the IT15 gene with the largest allele distribution.

\section{Lymphoblast testing}

Table 4 shows the results of the 12 duplex PCR combinations performed on single lymphoblasts. These include nine combinations where two microsatellites are amplified and three combinations where the CAG repeats and one microsatellite are amplified. Figure 2 shows an example of profiles obtained for four different duplex single-cell PCRs. The number of single cells tested in each series varied from 38 to 176 and a total of 1210 cells were tested. The PCR efficiency ranged between 81.6 and 100\%. A complete haplotyping was obtained in a range of 73.9 and $95.0 \%$ and a conclusive genotyping was obtained in a range of 87.4 and $100 \%$. The average ADO rate was $11.3 \%$. The overall contamination rate was $1.1 \%(3 / 282)$.

\section{Referrals}

Between October 1999 and December 2003, 43 couples have formulated a request for HD-PGD: 24 had had a PT (group I) and 19 did not (group II). In group I, we observed an equal sex distribution among the presymptomatic patients, 13 female and 11 male patients, but in group II we had more at-risk male patients than female patients, 12 and seven respectively $\left(\chi^{2}=0.21\right.$ with Yates correction for small samples, NS). The obstetrical history of the couples also differed between the two groups. Indeed, female average age is slightly higher in group I $(30.5 \pm 3.6$ versus $29.5 \pm 4.1$ years, NS) and couples of group I formulated their demand after a history of TOP (37\%). In group II, two couples had a voluntary TOP because they could not cope with the idea of transmitting the disease and one couple had a TOP after an exclusion PND test.

Two couples of group II declined and decided to go through PT and were finally not at risk for HD. In both cases, the male partner was at risk. The first couple 
Table 4 Results of single-cell testing

\begin{tabular}{|c|c|c|c|c|c|c|}
\hline Primer sets & $\begin{array}{l}\text { No. of } \\
\text { cells } \\
\text { analysed }\end{array}$ & $\begin{array}{c}\text { No. of } P C R \\
\text { with a signal } \\
\text { (\%) }\end{array}$ & $\begin{array}{c}\text { Complete } \\
\text { genotype (\%) }\end{array}$ & $\begin{array}{l}\text { Conclusive } \\
\text { genotype } \\
(\%)\end{array}$ & $A D O^{\mathrm{b}}(\%)$ & $\begin{array}{l}\text { Contamination } \\
\text { (No. of blanks) }\end{array}$ \\
\hline D4S3038-D4S127 & 90 & $82(91.1 \%)$ & $69(84.2 \%)$ & $73(89 \%)$ & $6(7 \%)$ & $0(20)$ \\
\hline D4S3038-D4S1614 & 146 & $138(94.5 \%)$ & $115(83.3 \%)$ & $127(92 \%)$ & $15(11 \%)$ & $0(19)$ \\
\hline D4S127-D4S412 & 154 & $141(91.6 \%)$ & $121(85.8 \%)$ & $128(90.8 \%)$ & $16(11 \%)$ & $0(20)$ \\
\hline D4S127-D4S3034 & 176 & $161(91.5 \%)$ & 119 (73.9\%) & $146(91.2 \%)$ & $22(14 \%)$ & $0(20)$ \\
\hline D4S1614-D4S3034 & 50 & 49 (98\%) & $39(79.6 \%)$ & $47(95.9 \%)$ & $9(18 \%)$ & $0(25)$ \\
\hline D4S1614-D4S412 & 38 & $31(81.6 \%)$ & $25(80.6 \%)$ & 31 (100\%) & $2(6.5 \%)$ & $0(16)$ \\
\hline D4S3034-D4S412 & 76 & $74(97.4 \%)$ & $69(93.2 \%)$ & $73(98.6 \%)$ & $5(6.8 \%)$ & $0(32)$ \\
\hline CAG-D4S127.2 & 146 & $143(98 \%)$ & $108(75.5 \%)$ & $125(87.4 \%)$ & $25(17.5 \%)$ & $0(30)$ \\
\hline CAG-D4S412.2 & 60 & $59(98.3 \%)$ & $47(79.7 \%)$ & $53(89.8 \%)$ & $12(20.3 \%)$ & $0(30)$ \\
\hline I1CAHD-D4S127.2 & 60 & $60(100 \%)$ & $57(95 \%)$ & $59(98.3 \%)$ & $3(5 \%)$ & $0(30)$ \\
\hline I1CAHD-D4S412.2 & 78 & $76(97.4 \%)$ & $69(90.8 \%)$ & 73 (96\%) & $5(6.6 \%)$ & $2(20)$ \\
\hline I1CAHD.2-CAG & 136 & $135(99.3 \%)$ & $122(90.4 \%)$ & $126(93.3 \%)$ & $11(8.1 \%)$ & $1(20)$ \\
\hline Total & 1210 & 1149 (95\%) & $960(83.6 \%)$ & $1061(92.3 \%)$ & $131(11.3 \%)$ & $3(282), 1.1 \%$ \\
\hline
\end{tabular}

${ }^{a}$ Correct genotype for at least one locus.

${ }^{b}$ Cells with an ADO for at least one locus.

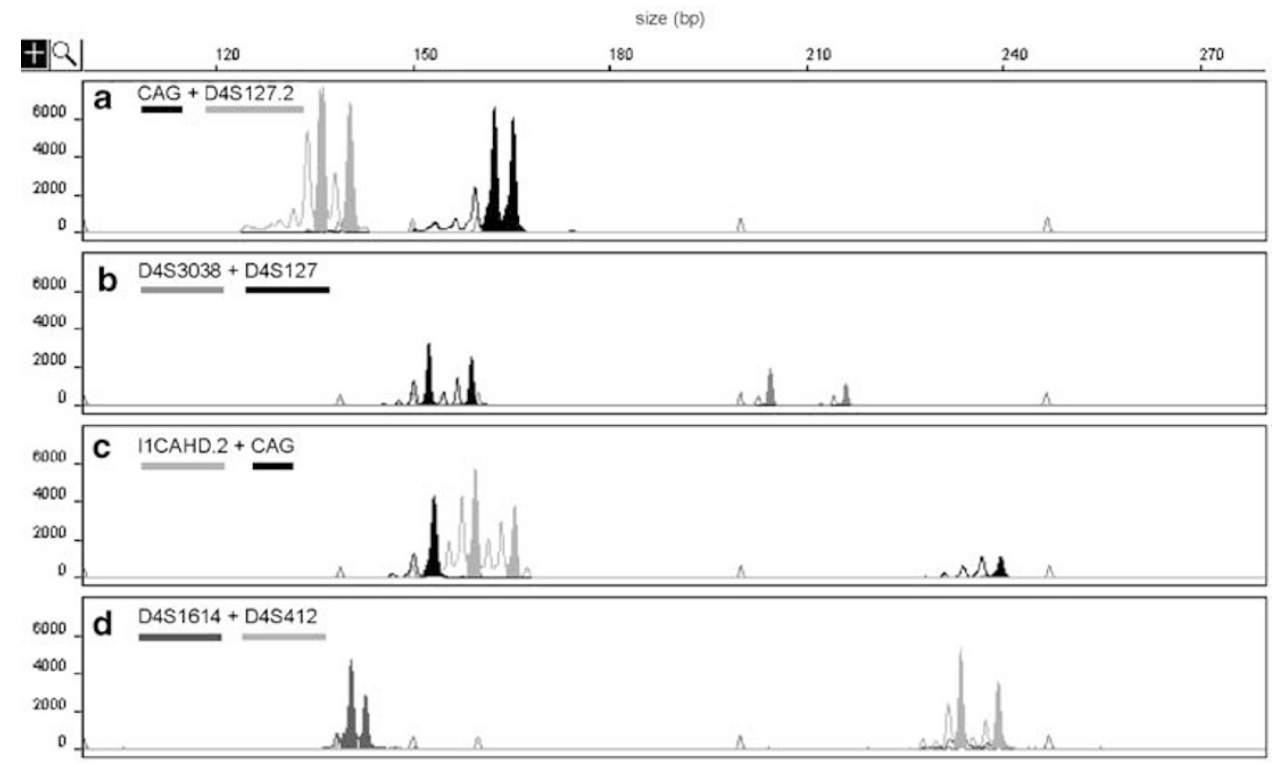

Figure 2 Examples of profiles obtained for four different duplex single-cell PCRs. Amplified loci are indicated on the top left of each panel and underlined with corresponding colours. Profiles $a, b$ and d were obtained after PCR on single lymphoblasts. Profile $c$ is the result of duplex PCR combining CAG and intron 1 microsatellite for a single blastomere of an affected embryo.

formulated their request before we were technically ready. Therefore, we were unable to give them a delay. This uncertainty may have prompted them to take the test. For the second one, PGD was available, but with a delay of 6 months.

\section{Clinical application of PGD in couples with a known genetic status}

Among our referrals, we tested 15 couples, 11 of whom were informative, three semi-informative and one noninformative.
Between May 2001 and December 2003, we performed 31 cycles for 11 couples (Table 5). Eight (25.8\%) of these cycles were cancelled because of a poor response to ovarian stimulation (five cycles), hyperstimulation risk (one cycle), cysts (one cycle) or very fast follicular growth (one cycle). A total of 23 cycles had an ovarian puncture. On average, 12.0 cumulus oocyte complexes (COCs) were retrieved and 9.9 oocytes injected. An average of 4.2 embryos were suitable for biopsy. In total, 34 embryos were diagnosed as unaffected leading to 15 embryo transfers with an average of 2.1 embryos per transfer. Three positive $\beta$-hCG measurements have been obtained: two ongoing pregnancies with 
Table 5 Summary of PGD cycles for groups I and II

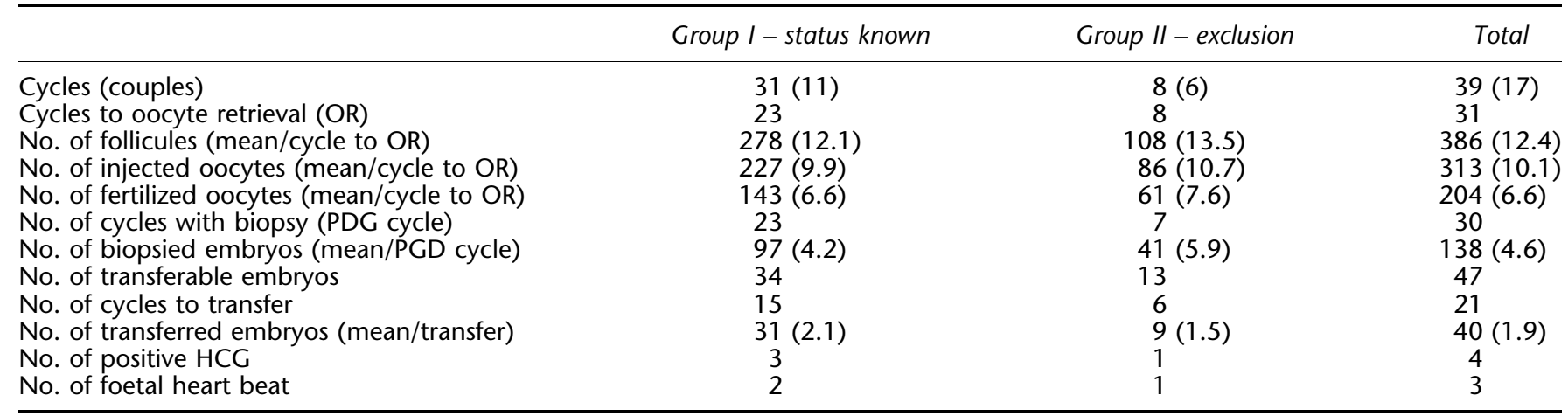

foetal heart beats and one clinical pregnancy without foetal heart beats. The majority of these cycles (17 out of 23) was performed using the simplex PCR for the CAG repeats. Five cycles were performed using the duplex PCR combining the CAG repeats and the D4S127 microsatellite marker. In total, we analysed 94 embryos and obtained a diagnosis for 75 of them (80\%). A total of 183 blastomeres were analysed and a PCR signal was obtained for 127 (69\%), with a complete haplotyping for 73 (57\%), a conclusive diagnosis for 118 (93\%) and an ADO for at least one locus in 53 (42\%). Three of 183 (1.6\%) blank controls were contaminated. Contamination did not lead to possible ambiguity of the result or misdiagnosis in any of the cases.

\section{Clinical application of PGD for couples not wishing to perform presymptomatic testing}

We performed 13 preliminary genetic analyses. For 10 of them, the analysis of the mother was sufficient and for three, we had to perform an additional analysis of the father. A PGD was possible for all of them. It is worth noting that the I1CAHD was informative in 11 of 13 cases.

Between May and December 2003, we performed eight cycles for six couples (Table 5). All had an ovarian puncture, but one cycle was cancelled because no embryo had reached the six-cell stage required for biopsy. On average 13.5 COCs were retrieved and 10.7 oocytes injected. An average of 5.1 embryos were suitable for biopsy. In total, 13 embryos were diagnosed as unaffected leading to six embryo transfers with an average of 1.5 embryos per transfer. One positive $\beta$-hCG was obtained. We had no requests to freeze at-risk embryos. Three cycles were performed using duplex PCR D4S412/D4S3034: one with D4S127/D4S512, one with D4S127/D4S3034 and one with D4S3038/D4S1614.

In total, we analysed 41 embryos and obtained diagnoses for 34 of them (83\%), 75 blastomeres were analysed and a PCR signal was obtained for 63 (84\%) with a conclusive diagnosis in 48 of these $(76 \%)$ and an ADO for at least one locus in 22 of these (35\%). Four of 75 (5.3\%) blank controls were contaminated. In one case, a fragment was observed near the cell during the tubing procedure and in the three other cases, the blastomere was lysed during biopsy and could not be properly rinsed before tubing. Contamination did not lead to possible ambiguity of the result or misdiagnosis in any of the cells.

\section{Discussion}

As a late-onset neurodegenerative syndrome, HD presents people having an affected parent with the difficult choice of whether to establish their genetic status before the appearance of any clinical sign. This is especially relevant since no treatment is available. The choice becomes even more stringent when a reproductive project takes place. Since the opening of our PGD centre, we have had 43 requests for HD-PGD. We have had both types of requests with an equal distribution in both groups (24 in group I and 19 in group II). Interestingly, in group I we had as many at-risk female patients as male patients. In contrast, in group II we observed more at-risk male patients than female patients. According to a recent European collaborative study, two-thirds of PND are by direct testing and onethird by exclusion testing. An equal female to male distribution was observed in the at-risk persons whatever type of PND was requested. ${ }^{15}$ In their 10-year experience in prenatal testing for $\mathrm{HD}$, Maat-Kievit et $a l^{16}$ noticed that there were more at-risk female patients in the direct PND testing group and an equal representation in the exclusion test group. Goizet et $a l^{17}$ noted that significantly more women (63\%) than men (37\%) requested presymptomatic testing and that even more women (64\%) than men (36\%) went through the entire procedure and obtained a result. ${ }^{17}$ Such a finding could explain the sex distortion we observed in our group II patients.

For group I patients, we developed one single direct PCR diagnosis based on determining the CAG repeats size and three duplex PCRs coamplifying the CAG repeat and one polymorphic marker. For group II patients, we developed 
nine duplex PCRs coamplifying two different polymorphic markers. During the set-up of these tests, we identified a new highly polymorphic CA repeat marker in intron 1 of the IT15 gene, referred to as I1CAHD. This marker shows a calculated maximal heterozygosity of $90 \%$. Because of its location in the first intron, its allele distribution and its high heterozygosity, it represents an excellent tool for the indirect diagnosis of HD. No duplex PCR using I1CAHD was used for these PGD cycles because the setting up was not finished. We will use it as often as possible for the future cycles since its intragenic localisation reduces the risk of meiotic recombination to nearly zero.

These tests have allowed us to treat 11 couples from group I and to obtain three pregnancies (two ongoing and one lost) and to treat six couples of group II and to obtain one ongoing pregnancy. In this limited series, we obtained quite a low pregnancy rate (19\%) compared to our general activity (28\% in 2003). We do not have an explanation for this and nothing in the literature suggests that HD-PGD should be more problematic than other diseases. One question remains open concerning the PGD exclusion procedure. Should we freeze the at-risk embryos? Indeed, if for any reasons the choice is made to go through a predictive test that turns out to be favourable, these embryos are not at risk anymore and the couple may ask for their transfer. For the moment, we do not have an answer and are not freezing these embryos.

The two groups of patients raise different ethical questions. Both feel the same time pressure. They would like to have their child as soon as possible so as to live with them in healthy conditions for a long time. The main concern with group I patients is the status of the healthy child who will have to suffer from the development of HD from the parent afflicted by the mutation. Such a situation will generate different burdens according to the family and social support received by the child. In the UK, it is a legal requirement to take into account the welfare of the future child, before offering any assisted conception treatment. ${ }^{18}$ We consider that it is not our task to morally judge the family environment, but neither is it possible to elude the question. We propose that the difficulty of the procedure and the necessity to see a geneticist before a first PGD attempt offer a time of reflection for the couple to evaluate their emotional stability and their desire for having a family. We are now appointing a psychologist who will see all our couples asking for HD-PGD. The second motive for requesting predictive testing, after "the relief from uncertainty", is "family planning". ${ }^{15,17}$ It would be of interest to know if the availability of a PGD exclusion test affects the percentage of couples who will go through the entire PT procedure.

The problem of the child's status is also relevant when the at risk person refuses PT, but only in 50\% of the cases since only one of every two patients will have inherited the mutation.
For group II patients, another problem is the need to proceed to an IVF and a PGD for all patients even if they are not at risk. This later point represents the major objection to exclusion testing. ${ }^{7}$ Another drawback of this method is the discarding of healthy embryos in $50 \%$ of the cases. This is also the case when sex determination is employed for recessive $\mathrm{X}$-linked diseases.

Concerning PND, exclusion testing means TOP for foetuses with a $50 \%$ risk of carrying the mutation. An unfavourable exclusion PND test will put the couple in a stressful situation since in such cases PT could allow the continuation of the pregnancy. ${ }^{19-21}$ In most reported cases, couples went ahead with the TOP. Tolmie et al reported $^{22}$ the lowest rate of declining TOP after an unfavourable exclusion test (three out of nine), which also raises the problem of the child's right not to know since, if the parent develops the disease, the child is at high risk of being affected. ${ }^{7}$ For all other reports, the TOP uptake was close to $100 \% .^{16}$ TOP after an unfavourable exclusion test has the same short-term consequences as any TOP, but also has long-term consequences. Indeed, 50\% of the couples who undertake a TOP are not carrying the mutation and will not develop the disease. They may learn their genetic status either because they decide to undergo PT or by staying asymptomatic when getting older. $^{23}$ At that moment, they will realise that TOP was unnecessary and they had aborted a normal foetus.

All these reasons strongly support the use of the PGD exclusion test since it avoids the burden of TOP. The major drawback of PGD procedure is the low rate of pregnancy obtained. We considered the possibility of offering a nondisclosure test as reported previously, ${ }^{8}$ but for ethical and practical reasons and in agreement with others, $7,24,25$ we declined this possibility and opted for the exclusion test even if it required further work to set up the technique.

We are conscious of the difficulties of PGD procedures and we are taking time to inform couples, but we do consider that if a couple is willing to undertake an exclusion test, PGD represents a less unfavourable option than PND.

\section{Acknowledgements}

We thank the IVF team at the SIHCUS-CMCO, Dr Karen Sermon and Dr Chris Rose for their helpful comments on this manuscript and Eponine Huen for her technical assistance. This work was supported by funds from Association Française contre les Myopathies (AFM), Association Française de Lutte contre la Mucoviscidose (AFLMVLM), Centre National de la Recherche Scientifique (CNRS), Institut National de la Santé et de la Recherche Médicale (INSERM) and Huntington Espoir.

\section{References}

1 Huntington's-Disease-Collaborative-Research-Group: A novel gene containing a trinucleotide repeat that is expanded and unstable on Huntington's disease chromosomes. Cell 1993; 72: 971-983. 
2 Tibben A, Duivenvoorden HJ, Vegter-van der Vlis $\mathrm{M}$ et al: Presymptomatic DNA testing for Huntington disease: identifying the need for psychological intervention. Am J Med Genet 1993; 48: 137-144

3 Laccone F, Engel U, Holinski-Feder E et al: DNA analysis of Huntington's disease: five years of experience in Germany, Austria, and Switzerland. Neurology 1999; 53: 801-806.

4 Harper PS, Lim C, Craufurd D: Ten years of presymptomatic testing for Huntington's disease: the experience of the UK Huntington's Disease Prediction Consortium. J Med Genet 2000; 37: $567-571$.

5 Sermon K, Goossens V, Seneca S et al: Preimplantation diagnosis for Huntington's disease (HD): clinical application and analysis of the HD expansion in affected embryos. Prenat Diagn 1998; 18: $1427-1436$.

6 Schulman JD, Black SH, Handyside A, Nance WE: Preimplantation genetic testing for Huntington disease and certain other dominantly inherited disorders. Clin Genet 1996; 49: 57-58.

7 Braude PR, De Wert GM, Evers-Kiebooms G, Pettigrew RA, Geraedts JP: Non-disclosure preimplantation genetic diagnosis for Huntington's disease: practical and ethical dilemmas. Prenat Diagn 1998; 18: 1422-1426.

8 Stern HJ, Harton GL, Sisson ME et al: Non-disclosing preimplantation genetic diagnosis for Huntington disease. Prenat Diagn 2002; 22: 503-507.

9 Viville S, Nisand I: Legal aspects of human embryos research and preimplantation genetic diagnosis in France. Hum Reprod 1997; 12: $2341-2342$.

10 Moutou C, Gardes N, Viville S: Multiplex PCR combining deltaF508 mutation and intragenic microsatellites of the CFTR gene for pre-implantation genetic diagnosis (PGD) of cystic fibrosis. Eur J Hum Genet 2002; 10: 231-238.

11 Hardy K, Handyside AH: Biopsy of cleavage stage human embryos and diagnosis of single gene defects by DNA amplification. Arch Pathol Lab Med 1992; 116: 388-392.

12 Rousseau F, Heitz D, Biancalana V, Oberle I, Mandel JL: On some technical aspects of direct DNA diagnosis of the fragile $\mathrm{X}$ syndrome. Am J Med Genet 1992; 43: 197-207.

13 Van Steirteghem AC, Nagy Z, Joris H et al: High fertilization and implantation rates after intracytoplasmic sperm injection. Hum Reprod 1993; 8: 1061-1066.
14 Wittemer C, Ohl J, Bettahar-Lebugle K, Viville S, Nisand I: A quantitative and morphological analysis of oocytes collected during 438 IVF cycles. J Assist Reprod Genet 2000; 17: 44-50.

15 Evers-Kiebooms G, Nys K, Harper P et al: Predictive DNA-testing for Huntington's disease and reproductive decision making: a European collaborative study. Eur J Hum Genet 2002; 10: $167-176$.

16 Maat-Kievit A, Vegter-van der Vlis $M$, Zoeteweij $M$ et al: Experience in prenatal testing for Huntington's disease in The Netherlands: procedures, results and guidelines (1987-1997). Prenat Diagn 1999; 19: 450-457.

17 Goizet C, Lesca G, Durr A: Presymptomatic testing in Huntington's disease and autosomal dominant cerebellar ataxias. Neurology 2002; 59: 1330-1336.

18 Lashwood A, Flinter F: Clinical and counselling implications of preimplantation genetic diagnosis for Huntington's disease in the UK. Hum Fertil (Camb) 2001; 4: 235-238.

19 Simpson SA, Zoeteweij MW, Nys K et al: Prenatal testing for Huntington's disease: a European collaborative study. Eur J Hum Genet 2002; 10: 689-693.

20 Simpson SA, Harper PS: Prenatal testing for Huntington's disease: experience within the UK 1994-1998. I Med Genet 2001; 38: $333-335$.

21 Lesca G, Goizet C, Durr A: Predictive testing in the context of pregnancy: experience in Huntington's disease and autosomal dominant cerebellar ataxia. J Med Genet 2002; 39: 522-525.

22 Tolmie JL, Davidson HR, May HM, McIntosh K, Paterson JS, Smith B: The prenatal exclusion test for Huntington's disease: experience in the west of Scotland, 1986-1993. J Med Genet 1995; 32: $97-101$.

23 Chapman E: Ethical dilemmas in testing for late onset conditions: reactions to testing and perceived impact on other family members. J Genet Couns 2002; 11: 351-367.

24 Evers-Kiebooms G, Fryns JP, Demyttenaere K et al: Predictive and preimplantation genetic testing for Huntington's disease and other late onset dominant disorders: not in conflict but complementary. Clin Genet 1996; 50: 275-276.

25 Geraedts JP, Liebaers I: Preimplantation genetic diagnosis for Huntington's disease; in Evers-Kiebooms G, Zoeteweij M, Harper P (eds): Prenatal Testing for Late Onset Neurogenetic Diseases. Oxford, UK: C2002 Bios Scientific Publishers Ltd., 2002. 